\title{
International Collaboration on a Sustainable Forestry Management OER Online Program - A Case Study
}

\author{
Min Qian (Michelle) Zeng', Hailan Chen ${ }^{2}$, Anil Shrestha ${ }^{1}$, Chris Crowley ${ }^{2}$, Emma Ng$^{1}$, \\ Guangyu Wang ${ }^{1}$
}

${ }^{1}$ Asia Forest Research Centre, the University of British Columbia, Canada, ${ }^{2}$ Centre of Teaching, Learning and Technology, the University of British Columbia, Canada

\begin{abstract}
Over time, forest education has had to adapt to keep up with global changes and to accommodate the needs of students and society. While facing pressing global issues like climate change, deforestation, illegal logging and food security, the role of higher forest education has shifted away from traditional teaching approaches and practices to methods that emphasize sustainable development, community-based management and environmental conservation in forestry. In doing so, forest education has cultivated human expertise that understands the complexity of ever-changing environments, masters state of the art technologies to manage forests and natural resources, and is capable of creating, communicating and implementing related policies in global communities and societies. In this context, educational technology and online learning enable flexible, accessible, effective, and high-quality forest education. A case study of a Sustainable Forest Management Online Program led by the Faculty of Forestry, University of British Columbia $(U B C)$ shows that appropriately integrating educational technologies into an internationally developed and recognized high quality curriculum is an effective way to create accessible and affordable forest education in meeting the demand of evolving societal and environmental conditions.
\end{abstract}

Keywords: forest education; online learning; educational technology; international collaboration, open educational resources 


\section{Introduction}

\subsection{Higher Forest Education in a Changing World}

The multitude of pressing global issues, including climate change, deforestation, and illegal logging, has underscored the need for forestry education to strive supporting sustainable forest management practices that accommodate natural cycles and ecological systems to promote the long-term health of the land and the people (CCIED, 2016). These practices often emphasize community-based management approaches and environmental conservation (Temu, Rudebjer, Kiyiapi, \& Lierop, 2005). Given the complexity of these practices, today's forestry graduates must be internationally strategic thinkers with a variety of skills (Längin, Ackerman, \& Lewark, 2004). In the dynamic context of globalization, advancing technologies, economic uncertainties, and changes in society values, higher education requires to meet the demand of emerging new field of forestry while for graduates, education will mean lifelong learning, and may need support from technologybased distance education to fulfill the needs of society (Owusu-Ansah, Neill, \& Haralson, 2011).

\subsection{Online Learning in Forestry Education}

The advantages of online learning are many including flexible hours and location, costeffectiveness, borderless collaboration, as well as access to current information and educational resources (Allred \& Smallidge, 2010). Even online, educators can maintain synchronous instruction through webinars, videoconferencing, and blended or flipped approaches. However, development costs, accessibility, and concerns from faculty members, may hinder integration of web-based technology in higher education (OwusuAnsah, et al., 2011). Despite the adoption of online learning, webinars and learning technology in many subject areas in Canada (Bates, 2017), and in American and European forest education (Bogdanou, Starr, Weatherall \& Leslie, 2013; Gleason, 2015), these technologies have yet to be fully utilized in higher forest education. As discussed by Längin, et al. (2004), the dearth of forestry online learning might be due to small student target groups, or the apprehension that computer-supported learning only trains theorists in a very practice-oriented field of science. Yet online learning may allow forestry universities to meet the new demands in forest and environmental education (Längin, et al., 2004).

\subsection{Purpose of the Paper}

This article attempts to discuss the effectiveness of a sustainable forestry management online open education resources (OER) program developed and implemented through international collaboration. The experience and lesson learned from the practices can be used for colleagues in developing online learning programs and OER during this challenging time amid global COVID -19 pandemic. 


\section{Planning and Practices}

A joint educational online program entitled Innovative Sustainable Forest Management Education in the Asia-Pacific Region, ${ }^{1}$, started being developed in 2014, is a series of online courses in sustainable forest management (SFM) with its content as OER. The program has been led by UBC Forestry in partnership with Beijing Forestry University (BFU), University of Melbourne (UM), University Putra Malaysia (UPM), and University of the Philippines Los Baños (UPLB) under the framework of the Asia Pacific Forestry Education Coordination Mechanism (AP-FECM) sponsored by the Asia-Pacific Network for Sustainable Forest Management and Rehabilitation (APFNet). The goal of the program is to improve access to education in the field of SFM, targeting to enhance teaching quality, curriculum enhancement and research capacity among forestry universities, policy makers and practitioners in the Asia Pacific region (Innes, Wang, \& Zeng, 2018). The AP-FECM sees the OER concept to be pivotal to the success of this endeavor.

As the only SFM online program of its kind, the joint educational program provides worldclass forestry education resources created and supported by leading professors and experts from internationally recognized universities around the world to over 10,000 students and professional learners from over 90 international economies since 2016.

\subsection{Program Development}

Forming an international content expert team, with central instructional design support from UBC, the program followed a modified ADDIE (Analyze, Design, Develop, Implement, and Evaluate) instructional design model to employ Mishra and Koehler's (2006) Technological Pedagogical Content Knowledge (TPCK) framework ensuring effective integration of technology into the content and pedagogy of course design and development.

The program aims to introduce updated SFM topics to global learners in an open learning environment. The course topics (changing landscapes of SFM, governance policy, community development, sustainable use of forest ecosystem services, forest resources management, ecosystem restoration and protection) were widely consulted with regional forestry universities and identified from reviews and surveys conducted by the AP-FECM, which demonstrated solid needs and interests of learners and larger societies. Content experts from regional forestry universities in the AP-FECM network were then invited to develop coursework. Together, these subject matter experts form an international collaborative development team with a broad knowledge in diverse approaches to management, ecosystems and forest-types. While developing contents, the international

\footnotetext{
${ }^{1}$ http://apfecm.forestry.ubc.ca/sfm-online-courses/
} 
experts worked on contents related to theory and local, regional and global practices as a case related to their assigned course, which has wider learning scope. Before course development, a three-day on-site course development workshop was held by UBC Forestry and UBC Centre of Teaching, Learning and Technology (CTLT) to conduct curriculum and course mapping, discuss applicable pedagogy, and introduce design principles for online learning using educational technologies. A team-based approach to content development, learning design and project management was established to support the entire program development combining knowledge of content, pedagogy and technology. During course development, instructional design and educational technology support were provided to help content experts in developing their online courses by providing content templates and through reviews and feedbacks on course outline, schedule, assessments, and module content.

As a result of these efforts, the final course design came to fruition. Each course features self-directed learning with content as Open Educational Resources (OER). Learning modules break down to topics for easy repurpose and typically consist of background information, video lectures, supplemental readings, self-tests, self-directed reflection questions, and self-directed discussions. With module-based format, it allows instructors to easily incorporate appropriate content into their own courses and allows institutions to customize and integrate the entire or 'parts of' each course to fit into their own education curricula and programs. This pedagogical model allows both self-paced learning and instructor-led learning to improve flexibility and learner engagement.

\subsection{Program Implementation}

The OER Course materials have been widely utilized or repurposed either partially or entirely by AP-FECM, participating universities, member universities of AP-FECM, and individual users in their learning, teaching, and research since 2016. Some examples of innovative pedagogical approaches of online teaching using the existing OER course materials include the following. In Course 3 (International Dialogue on Forestry Issues), learners were asked to preview the course content and bring questions to a classroom discussion held in a video conferencing session led by instructors at UBC as a part of undergraduate course. In Course 5 (Restoration of Degraded Forest Ecosystems and Forest Plantation Development), the lead professor in Australia blended the course materials into the University of Melbourne's Master of Forest Ecosystem Science. Graduate students experienced a combination of self-paced SFM online lectures, in-class discussions and hands-on fieldwork at a wide range of forest sites with fellow classmates. In 2017, 2018 and 2019, Course 1 (Sustainable Forest Management in a Changing World) and Course 5 (Restoration of Degraded Forest Ecosystem and Forest Plantation Development) were held as the open enrolment pilot courses. Learners were asked to study course materials and share localized practical experience in group discussions. They also conducted field work 
and present visual materials of local practices in relation to sustainable forest management and restoration of degraded forest, therefore exchanging practical and applicable knowledge have enriched experiential learning across the boundary.

\section{Key Outcomes}

The SFM online program demonstrates the benefits of international collaboration on using online educational technologies supporting teaching and learning practices which enrich the learning experience and initiate international collaborations to shape higher forest education. Since 2016, the SFM online program has attracted over 10,000 learners including students, faculty members and professionals from over 90 countries around the world. Realizing the innovative approach employed, the program was awarded the CNIERCIE Award 2016 in the category of Excellence and Innovation in the Integration of Technology in Educational Practices/Collaboration. Recognizing the contribution of forestry education in Asia-Pacific region, the program was the winner of the International Union of Forest Research Organizations (IUFRO) Best Forest Education Award-Tertiary in 2019. These awards recognized the excellence in innovative educational practices and the use of technology to support and advance learning in forestry education. These awards also advocate the importance of multi-national multi-university collaborative efforts in today's dynamic education landscape which enhance local, regional and global awareness of forest sustainability for educating future generation scientists, policy makers and practitioners.

Positive results were shown by two external program evaluations. The first evaluation was based on the user survey (70 completed responses) which analyzed the user experience on course design, learning outcomes, learner assessment, course materials, learning activities, lecture resource preferences, and course look-and-feel. The second evaluation covered the impacts of the SFM online courses, the online platform and the program on forestry education in the region, and its sustainability and feasibility for future development. Based on an analysis of the program evaluations, independent external report concluded that the development of a series of SFM courses for delivering essential knowledge and skills in sustainable forest management to global audiences was largely successful in achieving its objectives (Bigsby, H., 2016), and there were solid evidence showing the existing courses are viable with high quality (Xi, W., 2017).

Successful delivery of the repurposed the SFM online OER program could be found in sample post-course surveys. The program was designed to encourage and assist globalization and global cooperation in developing students' careers in forestry and the post-course surveys indicate that this was successful as over $80 \%$ of respondents reported that the course advanced their knowledge of SFM in both their home country and abroad (Fig. 1a). The program has met these outcomes as over $90 \%$ of respondents reported a 
deeper understanding of SFM and feel they can apply their knowledge in their careers (Fig. 1b).

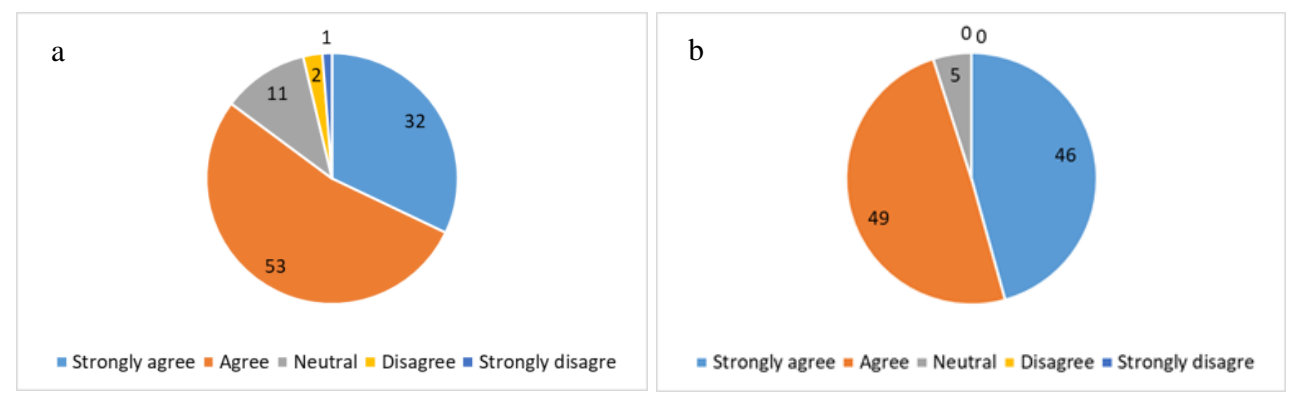

Figure 1: Learner Satisfaction on Knowledge Transfer expressed as \% (N=81). Source: Post Course Survey (2018).

Overall, more than $80 \%$ of respondents felt satisfied with the course and reported the online activities effectively enhanced their learning (Fig. 2a). Over $90 \%$ of respondents expressed their interest on pursuing another e-learning course (Fig. 2b). Thus, these experience of the users of SFM online program prove the effectiveness of online learning as a platform for forest education.

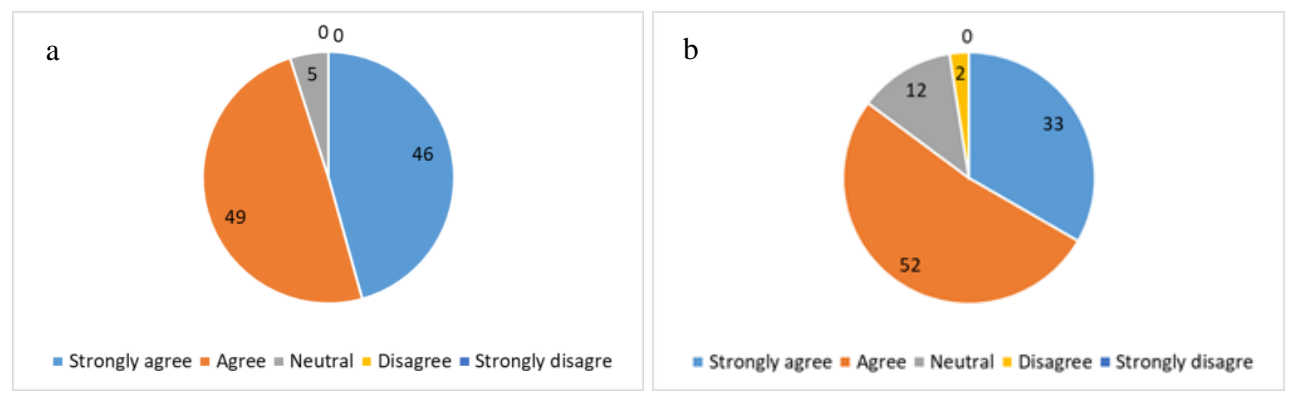

Figure 2: Learner Satisfaction on Knowledge Transfer expressed as \% (N=81). Source: Post Course Survey (2018).

\section{Conclusion}

The case study of the SFM online program showed that the integration of online technology, content and pedagogy is an effective way to produce new teaching and learning methods in higher forest education, which fulfills ever changing societal and environmental condition enriching student's learning experience ensuring wider public access. In this case study, it reveals that online educational technology could facilitate the cost-effective development of internationally recognized accredited forest education. Subject matter experts from the Asian-Pacific Region contributed their knowledge of multiple forest types and practices, providing learners with a more global understanding of forestry and SFM. 
The combination of educational technology, content and online pedagogy generates an improved form of forestry education that can access current information on global issues and support the interaction of peers and professionals around the globe without the constrains of geographical location and time. However, a significant amount of time and resources must be invested in the development and involvement of effective online courses. A team-based approach, sufficient preparation for course development and operation, ongoing financial, instructional and technical supports are critical components for the success of the international collaborative forest education program. We hope this joint effort is realizing a forestry lecturer's dream, described by L Längin, et al., (2004), to discuss [and learn] with a group of motivated students from different regions of the globe in one virtual classroom.

\section{Acknowledgements}

This paper is based on studies conducted along with the delivery of a series of online courses in sustainable forest management supported by the Asia-Pacific Network for Sustainable Forest Management (APFNet) and the Asia Pacific Forestry Education Coordination Mechanism (AP-FECM).

\section{References}

Allred, S. B., \& Smallidge, P. J. (2010). An educational evaluation of web-based forestry education. Journal of Extension , 48(6).

Alm, A., \& Byrne, J. (2011). Web-based learning for forestry professionals. Retrieved from https://www.iucn.org/content/web-based-learning-forestry-professionals

Bates, T. (Ed.) (2017). Tracking Online and Distance Education in Canadian Universities and Colleges: 2017. Vancouver BC: The National Survey of Online and Distance Education in Canadian Post-Secondary Education.

Bigsby, H. (2016). Evaluation Report - Innovative Sustainable Forest Management Education in the Asia Pacific Region.

Bogdanou, T., Starr C. B., Weatherall, A., \& Leslie, A.D. (2013). Use of the internet and social media in the forestry profession in the United Kingdom. International Forestry Review, 15 (2), 2013.

CCICED, China Council for International Cooperation on Environment and Development (2016). South-South Cooperation for Ecological Civilization (Draft). Paper from the Annual Conference of CCICED. China.

Gleason, D. A. (2015). Explore Oregon forests: a web-based educational tool for connecting forestry and tourism (Master's Thesis). Retrieved from http://hdl.handle.net/1957/58010

Innes, J. L., Wang, G. Y., \& Zeng, M. Q. (2018), Growing Higher Forestry Education in A Changing World - Analysis of Higher Forestry Education in the Asia Pacific Region. 
(APFNet \& AP-FECM, Eds.). China: China Forestry Publication House. Retrieved from https://apfecm.sites.olt.ubc.ca/files/2018/05/GROWINGHIGHERFORESTRYEDUCA TIONINACHANGINGWORLD-Final.pdf

Längin, D. W., Ackerman, P. A., \& Lewark S. (2004). Internet-based learning in higher forestry education. Unasylva, 55(216), 39-44. Retrieved from http://www.fao.org/3/y5382e/y5382e13.pdf

Mishra, P., \& Koehler, M. J. (2006). Technological Pedagogical Content Knowledge: A Framework for Teacher Knowledge. Teachers College Record, 108(6), 1017-1054. doi: 10.1111/j.1467-9620.2006.00684.x

Owusu-Ansah, A., Neill, P., \& Haralson, M. K. (2011). Distance Education Technology: Higher Education Barriers during the First Decade of the Twenty-First Century. Online Journal of Distance Learning Administration, 14(2). Retrieved from https://www.westga.edu/ distance/ojdla/summer142/ansah_142.html.

Post Course Survey. (2018). 2018 Offering_Post-Course Survey, Internal report of Faculty of Forestry, the University of British Columbia, Unpublished.

Temu, A. B., Rudebjer, P. G., Kiyiapi, J., \& van Lierop, P. (2005). Forestry education in sub-Saharan Africa and Southeast Asia: Trends, myths and realities. Rome, Italy: Food and Agriculture Organization. Retrieved from http://old.worldagroforestry.org/downloads/Publications/PDFS/B13959.pdf 